\title{
PERUBAHAN FUNGSI SOSIAL ASRAMA PANTI WYATA GUNA MENURUT PERATURAN MENTERI SOSIAL NO.18 TAHUN 2018 DIKAITKAN DENGAN UNDANG-UNDANG NO.8 TAHUN 2016 TENTANG PENYANDANG DISABILITAS
}

\author{
oleh: \\ CINDY DESIANA \\ HANA KRISNAMURTI
}

\begin{abstract}
ABSTRAK
Penyandang Disabilitas adalah setiap orang yang mengalami keterbatasan fisik, intelektual, mental, dan/ atau sensorik dalam jangka waktu lama yang dalam berinteraksi dengan lingkungan dapat mengalami hambatan dan kesulitan untuk berpartisipasi secara penuh dan efektif dengan warga Negara lainnya berdasarkan kesamaan hak. Berdasarkan kesamaan hak, perubahan fungsi sosial panti Wyata Guna menjadi balai rehabilitasi dalam Peraturan Menteri Sosial yang tidak mengacu kepada peraturan di atasnya yaitu UndangUndang Penyandang Disabilitas. Regulasi yang dibuat tidak berorientasi kepada kemaslahatan kelompok rentan yang seharusnya mendapat kemudahan aksebilitas dalam mengembangkan diri, sehingga dalam melaksanakan fungsi sosialnya tidak mendapat diskrimanasi dalam hal kesetaraan kesempatan guna mencapai kehidupan yang sejahtera. Penelitian ini bertujuan untuk mengetahui dampak dari perubahan fungsi sosial asrama panti Wyata Guna terhadap para penyandang disabilitas dan upaya penanggulangan agar hak penyandang disabilitas Wyata Guna tetap dilaksanakan. Metode pendekatan yang digunakan adalah yuridis normatif yaitu penelitian yang dilakukan berdasarkan bahan hukum utama dengan cara menelaah teori-teori, konsep-konsep, asas-asas hukum, taraf sinkronisasi hukum secara vertikal, serta peraturan perundang-undangan. Spesifikasi penelitian bersifat deskriptif analitis yaitu menerangkan atau menggambarkan masalahmasalah yang terjadi pada objek penelitian untuk kemudian di analisis. Analisis data yang digunakan adalah yuridis kualitatif, yaitu analisis yang dilakukan bertitik tolak dari analisis empiris, yang dalam pendalamannya dilengkapi dengan normatif. Berdasarkan hasil analisis ditarik kesimpulan secara deduktif, yaitu cara berpikir yang didasarkan pada fakta- fakta yang bersifat umum untuk kemudian ditarik suatu kesimpulan yang bersifat khusus. Hasil dari penelitian ini adalah perubahan fungsi sosial panti Wyata Guna terhadap para penyandang disabilitas menyebabkan para penyandang disabilitas netra yang sudah tinggal di panti tersebut menjadi kehilangan haknya karena adanya terminasi waktu dan pembatasan jumlah penyandang disabilitas sebagai penerima manfaat. Upaya penanggulangan agar hak para penyandang disabilitas tetap dilaksanakan adalah melakukan evaluasi terhadap kebijakan tersebut sehingga dapat mengetahui efektivitas dari peraturan yang dibuat dan dapat menentukan langkah-langkah selanjutnya.
\end{abstract}

Kata Kunci: Disabilitas,Kesejahteraan Sosial, Pelayanan Sosial

\section{PENDAHULUAN}

\section{Latar Belakang Masalah}

Pasal 1 Undang-Undang No.11 Tahun 2009 Tentang Kesejahteraan Sosial (selanjutnya disingkat Undang-Undang Kesejahteraan Sosial) menyatakan, kesejahteraan sosial adalah kondisi terpenuhinya kebutuhan material, spiritual, dan sosial warga Negara 
agar dapat hidup layak dan mampu mengembangkan diri, sehingga dapat melaksanakan fungsi sosialnya. Untuk mencapai kesejahteraan sosial maka diperlukan adanya pelayanan yang diberikan Negara untuk masyarakat yang memiliki masalah sosial. Pasal 5 ayat (2) Undang-Undang Kesejahteraan Sosial menjelaskan: "Memprioritaskan kepada mereka yang memiliki kehidupan tidak layak dan masalah sosial". Masalah sosial yaitu kesenjangan yang terjadi di antara situasi yang ada dengan situasi yang seharusnya. Difabel, disabilitas, atau keterbatasan diri adalah salah satu contoh masalah sosial.

Disabilitas merupakan orang yang mempunyai kelainan dan keterbatasan yang bersifat fisik atau mental. Istilah disabilitas digunakan dalam konvensi PBB (Perserikatan Bangsa-Bangsa) mengenai konvensi hak-hak penyandang disabilitas dan juga digunakan dalam Undang-Undang Nomor 8 Tahun 2016 Tentang Penyandang Disabilitas (selanjutnya disingkat Undang-Undang Penyandang Disabilitas). Pelayanan sosial dalam hal ini panti untuk para penyandang disabilitas yang ketersediaannya tidak dapat menampung para penyandang disabilitas menjadi suatu permasalahan. Keberadaan panti yang membantu mempermudah akses para penyandang disabilitas untuk menjalani pendidikan di Kota Bandung sekarang ini sudah tidak menjadi tanggung jawab pemerintah karena terjadi perubahan fungsi sosial asrama panti yang menjadi balai rehabilitasi. Pelayanan sosial sangatlah penting dan besar pengaruhnya jika dilaksanakan tepat sasaran. Pasal 2 UndangUndang Nomor 8 tahun 2016 tentang Penyandang Disabilitas (selanjutnya di singkat Undang-Undang Penyandang Disabilitas) menjelaskan : Pelaksanaan dan pemenuhan hak penyandang disabilitas berasaskan : huruf $\mathrm{c}$ tanpa diskriminasi, huruf $\mathrm{f}$ kesamaan kesempatan, huruf $\mathrm{j}$ inklusif, dan huruf k perlakuan khusus dan perlindungan lebih.

Keterbatasan fisik para penerima manfaat yang sedang melanjutkan pendidikan ke jenjang yang lebih tinggi membuat asrama panti di Wyata Guna Bandung menjadi hal penting guna menghindari hambatan dan kesulitan dalam kegiatannya sehari-hari secara penuh dan efektif dengan warga negara lainnya. Hal ini menjadi sebuah urgensi tersendiri karena dengan di implementasikannya Peraturan Menteri Sosial Nomor 18 Tahun 2018, sarana prasarana sebagai penunjang dalam keberlangsungan pendidikan para penyandang disabilitas menjadi terbatas karena adanya terminasi waktu. Panti sebagai bagian dari pelayanan sosial yang diberikan oleh Negara seharusnya mendapat perlindungan dengan tidak ditiadakannya fasilitas tersebut. Sejatinya, peraturan yang dibuat disesuaikan dengan kebutuhan dan harapan masyarakat agar tercipta suatu keadilan.

Penulis akan meneliti menggunakan teori Keseimbangan Pemerintahan (good governance) karena teori tersebut membahas mengenai pelayanan. Pelayanan dapat mempercepat pekerjaan pelayanan, mempermurah biaya pelayanan dan memperbaiki mutu pelayanan. Teori keseimbangan pemerintahan sangat penting untuk dilaksanakannya perbaikan yang dalam hal ini ialah mutu pelayanan agar lebih disesuaikan dengan kebutuhan masyarakat. Pemerintah diharapkan bisa lebih berhati-hati dalam menyusun kebijakan, artinya kebijakan yang dibuat harus dapat dipertanggung jawabkan secara nalar yang berorientasi untuk kemaslahatan masyarakat Indonesia secara umum.

Teori Keseimbangan Pemerintahan atau yang sering disebut dengan Good Govermance hadir untuk menjembatani pelaksanaan pemerintahan dan administrasi Negara dalam memecahkan masalah publik. Suatu kebijakan sosial yang diterapkan memiliki konsekuensinya tersendiri, seperti bersifat positif maupun bersifat negatif. Konsekuensi tersebut muncul dikarenakan adanya ketidak sesuaian regulasi dengan apa yang masyarakat butuhkan. Maka dari pada itu, untuk mencapai kesejahteraan sosial maka dalam menyusun atau menetapkan kebutuhan masyarakat sebaiknya mengikutsertakan pihak yang terkait.

Pasal 4 huruf c Undang-Undang Pelayanan Publik menjelaskan bahwa penyelenggaraan publik berasaskan kesamaan hak, yang artinya pemberian pelayanan tidak membedakan suku, ras, agama, golongan, gender, dan status ekonomi. Selain berasakan 
kesamaan hak, Pasal 4 huruf j Undang-Undang Pelayanan Publik pun berasaskan rentan, yang artinya pemberian kemudahan terhadap kelompok rentan sehingga tercipta keadilan dalam pelayanan.

Kebijakan Menteri dalam Peraturan Menteri Sosial Nomor 18 Tahun 2018 seharusnya berorientasi kepada kepentingan masyarakat. Menteri memiliki wewenang dalam menyusun atau menetapkan kebijakan seharusnya mengikutsertakan pihak terkait yang dalam hal ini penyandang disabilitas, agar kebijakan yang dibuat dapat disesuaikan dengan kebutuhan seluruh lapisan masyarakat.

Memberikan pelayanan sosial yang baik merupakan implementasi dari keseimbangan pemerintahan dan juga bagian dari hak asasi manusia yang tidak memperkenankan diskriminasi dan perbudakan. Oleh karena itu, penyandang disabilitas harus dilindungi dan dipertahankan haknya agar mendapat kesempatan yang sama dalam hal ini pendidikan.

Hal tersebut yang menjadi alasan penulis tertarik untuk meneliti permasalahan ini adalah bahwa setiap warga negara mempunyai hak yang sama untuk mendapatkan kesejahteraan dalam hidupnya. Maka dari pada itu, penulis tertarik untuk meneliti ketidakselarasan yang terjadi pada regulasi yang dibuat. Penelitian ini dilakukan di Balai, para disabilitas netra mengalami tindak pengusiran dan merupakan tempat terjadinya aksi penolakan perubahan fungsi sosial yang dilakukan oleh Unit Pelaksana Teknis (UPT) dibawah naungan Kementerian Sosial Republik Indonesia (RI), untuk penyandang disabilitas sensorik netra di Provinsi Jawa Barat khususnya Kota Bandung.

\section{Identifikasi Masalah}

1. Bagaimanakah Dampak Dari Perubahan Fungsi Sosial Asrama Panti Wyata Guna Terhadap Para Penyandang Disabilitas?

2. Bagaimanakah Upaya Penanggulangan Agar Hak Para Penyandang Disabilitas Wyata Guna Tetap Dilaksanakan?

\section{PEMBAHASAN}

\section{Dampak Perubahan Fungsi Sosial Asrama Panti Wyata Guna Terhadap Penyandang Disabilitas}

Undang-Undang dan peraturan dibawahnya saat ini dibentuk untuk mewujudkan cita- cita dan tujuan-tujuan Negara. Agar tujuan Negara yang dalam hal ini mencerdaskan kehidupan bangsa dapat tercapai, maka perlu ditunjang dengan sumber daya manusia yang terus dikembangkan. Cara efektif untuk mengembangkan sumber daya manusia ialah dengan pendidikan yang memadai. Karena dengan pendidikan, upaya peningkatan kemampuan dan potensi menjadi lebih luas.

Jika asrama panti Wyata Guna beralih ke balai rehabilitasi maka layanan sosial untuk tinggal menjadi singkat karena adanya terminasi waktu yang menjadi 6 bulan. Jika dilihat dari sisi Teori Keseimbangan Pemerintah (Good Governance), kasus yang terjadi di Wyata Guna seharusnya pemerintah mendukung kesadaran para mahasiswa dan mahasiswi penyandang disabilitas netra yang mempunyai keinginan untuk mengembangkan potensi dan wawasan ke tingkat yang lebih tinggi dengan tidak merubah fungsi sosial dari asrama panti tersebut.

Penyelenggaraan Good Governance merupakan bagian dari komitmen untuk melaksanakan perubahan ke arah yang lebih baik, karena kualitas sumber daya manusia yang baik merupakan pencapaian bangsa yang maju. Berkaitan dengan hal ini, sulitnya penyandang disabilitas mendapat kesempatan bekerja merupakan salah satu gejala dari 
kurangnya pendidikan yang dimiliki. Pelatihan vokasional yang didapat pada saat penyandang disabilitas menjadi penerima manfaat tidak menjamin berkembangnya kualitas hidup pada saat terjun di dunia masyarakat. Ditambah dengan stigma masyarakat yang memandang negatif kinerja penyandang disabilitas. Dampak dari perubahan fungsi asrama panti wyata guna tentu sangat berpengaruh terhadap pengembangan diri para penyandang disabilitas netra yang sudah berstatus sebagai mahasiswa dan mahasiswi.

Faktor pendidikan juga mempengaruhi jumlah pendapatan, sehingga penyandang disabilitas yang tidak memiliki latar belakang pendidikan dari Perguruan Tinggi memiliki kecenderungan kualitas hidup yang tidak sejahtera. Untuk mewujudkan tujuan nasional seperti memajukan kesejahteraan umum dan mencerdaskan kehidupan bangsa, diperlukan adanya kerja sama atau gotong royong yang merupakan pengamalan dari sila ketiga yang berbunyi : Persatuan Indonesia. Indonesia akan sulit menjadi Negara maju dan berkembang jika kualitas sumber daya manusianya tidak diperhatikan. Dengan dibekali pendidikan yang cukup, pola pikir, wawasan dan kesempatan bekerja pun menjadi lebih luas.

Adanya kesadaran untuk melanjutkan pendidikan yang lebih tinggi, hal tersebut telah menunjukan kepedulian akan pentingnya menaikan sumber daya manusia dari kelompok mereka sendiri agar stigma masyarakat yang meragukan kemampuan para penyandang disabilitas netra dengan sebelah mata tidak dapat dibuktikan. Jika dikaitkan dengan Teori Keseimbangan Pemerintahan (good govermance), tentu dapat terlihat bahwa dalam kasus yang terjadi di wyata guna jelas tidak menerapkan prinsip keefektifan dan efisiensi. Keefektifan disini dapat dianalogikan dari peraturan yang dibuat tidak sesuai dengan kebutuhan para penyandang disabilitas sehingga peraturan yang dibuat menjadi tidak efektif dalam pelaksanaannya, dan efisiensi dapat dianalogikan dari waktu yang diperlukan untuk perjalanan dari panti ke kampus yang secara aksebilitas lebih mudah dijangkau karena lokasi Wyata Guna yang strategis.

Undang-Undang No.9 Tahun 2016 Tentang Penyandang Disabilitas (selanjutnya disingkat Undang-Undang Penyandang Disabilitas) menjelaskan hak-hak penyandang disabilitas seperti : Pertama, kesamaan kesempatan yaitu memberikan peluang atau menyediakan akses kepada penyandang disabilitas untuk menyalurkan potensi dalam segala aspek penyelenggaraan Negara dan masyarakat. Kedua, hak untuk tidak mendapat diskriminasi seperti pembatasan dan pengucilan terkait kondisi disabilitasnya. Ketiga, aksebilitas yaitu kemudahan yang disediakan guna mewujudkan kesaman kesempatan. Keempat, pelayanan publik sebagai rangkaian kegiatan dalam rangka pemenuhan kebutuhan pelayanan atas barang, jasa, dan/atau pelayanan administratif. Kelima, mewujudkan taraf kehidupan penyandang disabilitas yang lebih berkualitas dan memastikan upaya pemajuan untuk mengembangkan diri serta mendayagunakan seluruh kemampuan sesuai bakat dan minat yang dimilikinya. Keenam, penyandang disabilitas memiliki hak hidup, bebas dari stigma dan pelabelan negatif terkait kondisi disabilitasnya, privasi, keadilan dan perlindungan hukum, mendapatkan pendidikan yang bermutu pada satuan pendidikan di semua jenis, jalur, dan jenjang pendidikan secara inklusif dan khusus, memperoleh pekerjaan yang diselenggarakan oleh pemerintah, pemerintah daerah atau swasta tanpa diskriminasi, kewirausahaan dan koperasi, kesehatan, politik, keagamaan, keolahragaan, kebudayaan dan pariwisata, kesejahteraan sosial, aksebilitas, pelayanan publik yang mudah diakses, perlindungan dari bencana, habilitasi dan rehabilitasi, konsesi, pendataan, hidup secara mandiri dan dilibatkan dalam masyarakat, berekspresi, berkomunikasi dan memperoleh informasi, berpindah tempat dan kewarganegaraan, bebas dari tindakan diskriminasi, penelantaran, penyiksaan, dan eksploitasi. Ketujuh, hak untuk mendapat perlindungan khusus, dilindungi kepentingannya dalam pengambilan keputusan, pemenuhan kebutuhan khusus, perlakuan yang sama dengan anak lain untuk mencapai integrasi sosial dan pengembangan individu. 


\section{Upaya Penanggulangan Agar Hak Penyandang Disabilitas Wyata Guna Tetap Dilaksanakan}

Ketidaksesuaian implementasi dengan norma hukum yang dibuat dikarenakan adanya peraturan yang tumpang tindih sehingga dalam pelaksanaannya menjadi tidak sesuai. Problematika seperti ini akan terus terjadi jika dalam proses pembuatan peraturan tidak melakukan proses pengharmonisasian terlebih dahulu. Proses pengharmonisasian mempunyai peran penting karena dengan demikian diharapkan tidak terjadi atau mengurangi tumpang tindih dalam peraturan yang ada.

Tata kelola pemerintahan yang baik merupakan tujuan dari Teori Keseimbangan Pemerintah (Good Governance), karena dengan kepemerintahan yang baik maka potensi pembangunan yang merupakan salah satu dari tujuan pemerintah akan tercapai. Menteri sebagai lembaga Negara yang diberi kekuasaan untuk mengurusi bidang tertentu jika menerapkan good governance maka segala pengambilan keputusan yang menyangkut alokasi sumber daya pembangunan akan memperhatikan kepentingan mereka yang paling lemah (rentan).

Peran pemerintah melalui kebijakan publik merupakan komponen yang sangat penting dikarenakan dengan adanya fasilitas pelayanan dalam bentuk panti yang diperuntukan untuk mempermudah aksebilitas para penyandang disabilitas selama masa pendidikannya, merupakan faktor pendorong terciptanya pelayanan sosial bagi orang yang memiliki keterbatasan fisik guna menghindari hambatan dan kesulitan dalam menjalankan fungsi sosial. Upaya penanggulangan agar hak penyandang disabilitas tetap dapat dilaksanakan dapat dilakukan dengan cara valuasi kebijakan. Evaluasi dilakukan agar dapat mengetahui efektivitas peraturan yang dibuat sudah tepat dengan sasarankah atau tidak. Sebab dengan evaluasi kebijakan kita dapat mengetahui pengukuran hasil yang dicapai dengan diberlakukannya aturan tersebut dan dapat menentukan langkah-langkah selanjutnya. Selanjutnya dengan memperbaiki mutu pelayanan, seperti yang dijelaskan didalam Teori Keseimbangan Pemerintahan (good govermance) bahwa pemerintahan yang baik ialah pemerintah yang memperbaiki mutu pelayanan dengan menyesuaikan kebutuhan warga negaranya. Berpikir strategis juga diperlukan dengan memilih sasaran dalam membuat keputusan yang diperlukan untuk mencapai visi yang telah disepakati. Visi merupakan kondisi yang diperlukan guna membentuk masa depan bangsa.

\section{PENUTUP}

\section{Kesimpulan}

Peraturan Menteri Sosial Nomor 18 Tahun 2018 tidak sesuai dengan UndangUndang Nomor 8 Tahun 2016 sehingga bertentangan dengan peraturan yang lebih tinggi dan berdampak kepada kesejahteraan hidup karena tidak mendapat fasilitas tinggal di tempat pelayanan sosial yang seharusnya menjadi wadah dalam mempermudah aksebilitas mahasiswa dan mahasiswi yang sedang mengembangkan kemampuan untuk meningkatkan kualitas hidup. Hal tersebut mempengaruhi kesempatan dalam bekerja sehingga menimbulkan kesenjangan sosial dan keahlian yang didapat pada saat pelatihan berkesinambungan dengan pekerjaan yang dijalani para penyandang disabilitas netra, dan penghasilan yang didapat tidak mencukupi sehingga tidak tercipta kehidupan sejahtera.

Upaya penanggulangan agar hak para penyandang disabilitas tetap dapat dilaksanakan yang pertama, pihak pemerintah daerah sebagai penyelenggara pemerintahan daerah yang mewakili pemerintahan pusat hendaklah reponsif dalam menyelesaikan persoalan yang terjadi, sehingga dapat memberikan solusi dan mencari jalan keluar bersama. 
Kedua, melakukan evaluasi terhadap kebijakan tersebut sehingga dapat mengetahui efektivitas dari peraturan yang dibuat dan dapat menentukan langkah-langkah selanjutnya. Ketiga, dengan anggaran dana guna melaksanakan standar nasional sumber daya manusia penyelenggara kesejahteraan sosial maka fasilitas asrama panti yang sebelumnya belum ada dapat diselenggarakan dan diperuntukan khusus kepada penyandang disabilitas yang sedang menjalani program studi di Perguruan Tinggi agar aksebilitasnyaterjamin.

\section{Saran}

Diperlukan pengidentifikasian yang lebih mendalam terhadap kebutuhan masyarakat dalam membuat sebuah regulasi, karena seiring berkembangnya zaman tentu kebutuhan yang diperlukan pun akan berbeda. Sehingga peraturan yang dibuat memberikan kedayagunaan dengan disesuaikannya berdasarkan hierarki perundang-undangan. Diperlukan Komisi Nasional Disabilitas sebagai lembaga non struktural yang bersifat independen untuk menjembatani komunikasi antara Penyandang disabilitas dengan pemerintah, seperti yang Undang-Undang Nomor 8 Tahun 2016 tentang Penyandang Disabilitas pada Pasal 132 ayat (1) jelaskan : Komisi Nasional Disabilitas mempunyai tugas melaksanakan pemantauan, evaluasi, dan advokasi pelaksanaan penghormatan, perlindungan, dan pemenuhan hak penyandang disabilitas.

\section{DAFTAR PUSTAKA}

\section{A. Buku}

Edi Suharto, Analisis Kebijakan Publik, Alfabeta, Bandung, 2012.

Herdiansyah, Kualitas Pelayanan Publik, Gava Media, Yogyakarta, 2018

Inu Kencana Syafiie, Etika Pemerintahan, PT Rineka Cipta, 2011.

Jimly Assihiddiqie, Hukum Tata Negara dan Pilar-Pilar Demokrasi, Konstitusi Press, Jakarta, 2005.

Mukti Fajar dan Yulianto Achmad, Dualisme Penelitian Hukum Normatif \& Empiris, Pustaka Pelajar, Yogyakarta.

M. Ryass Rasjid, Desentralisasi dalam Menunjang Pembangunan Daerah dalam Pembangunan Administrasi di Indonesia, Pustaka LP3ES, Jakarta, 1998.

Mestika Zed, Metode Penelitian Kepustakaan, Yayasan Pustaka Obor Indonesia, Jakarta, 2014.

Maria Farida Indrati S, Ilmu Perundang-Undangan, Kanisius, 2019.

Mansour Faqih (et al), Menegakkan Keadilan dan Kemanusiaan, Pegangan Untuk Membangun Gerakan HAM, Insist Press, Yogyakarta, 2003.

Sumarto Hetifa Sj, Inovasi Partisipasi dan Good Govermance, Yayasan Obor Indonesia, Bandung, 2003.

Sedamayanti, Good Governance "Kepemerintahan Yang Baik" \& Good Corporate Governance "Tata Kelola Perusahaan Yang Baik", CV Mandar Maju, Bandung, 2012.

Sirajuddin, Didik Sukriono, Winardi, Hukum Pelayanan Publik, Setara Press, Malang, 2011.

\section{B. Peraturan Perundang-Undangan}

Undang-Undang Dasar Republik Indonesia Tahun 1945

Undang-Undang Nomor 8 Tahun 2016 Tentang Penyandang Disabilitas.

Undang-Undang Nomor 11 Tahun 2009 Tentang Kesejahteraan Sosial.

Undang-Undang Nomor 19 Tahun 2011 Tentang Pengesahan Convention On

The Rights of Persons With Disabilities (Konvensi Mengenai Hak-Hak 
Penyandang Disabilitas).

Undang-Undang Nomor 25 Tahun 2009 Tentang Pelayanan Publik.

Undang-Undang Republik Indonesia Nomor 6 Tahun 1974 Tentang Ketentuan- Ketentuan Pokok Kesejahteraan Sosial.

Undang-Undang Nomor 39 Tahun 1999 Tentang Hak Asasi Manusia.

Peraturan Presiden Republik Indonesia Nomor 7 Tahun 2005 Tentang Rencana

Pembangunan Jangka Menengah Nasional Tahun 2004-2009.

Peraturan Menteri Sosial Nomor 18 Tahun 2018 Tentang Organisasi Dan Tata Kerja Unit Pelaksana Teknis Rehabilitasi Sosial Penyandang Disabilitas Di Lingkungan Direktorat Jenderal Rehabilitasi Sosial.

Keputusan Menteri Pendayagunaan Aparatur Negara Nomor 63 Tahun 2003 Tentang Pedoman Umum Penyelenggaraan Pelayanan Publik.

\section{Sumber Lain}

https://kbbi.web.id/asas (yang diakses pada hari Rabu tanggal 6 Mei 2020 pukul 13.47 WIB).

https://www.cnnindonesia.com/nasional/20200115140753-20-465574/ (yang diakses pada hari Selasa tanggal 18 Februari 2020 pukul 15.49 WIB).

www.pengertianmenurutparaahli.net/pengertian-fasilitas/ (yang diakses pada hari Kamis tanggal 20 Februari 2020 pukul 08.20 WIB).

https://ngobrolinhukum.wordpress.com/2014/08/09/data-sekunder-dalam-penelitian-hukumnormatif/ (yang diakses pada hari Jumat tanggal 3 April pukul 19.20 WIB). 